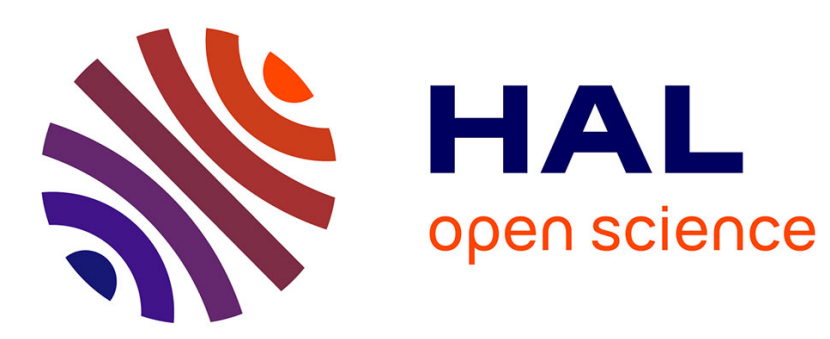

\title{
Localisation par canalisation des impuretés implantées dans le ZnTe
}

\author{
A. Bontemps, J. Fontenille, E. Ligeon, R. Danielou
}

\section{To cite this version:}

A. Bontemps, J. Fontenille, E. Ligeon, R. Danielou. Localisation par canalisation des impuretés implantées dans le ZnTe. Revue de Physique Appliquée, 1976, 11 (1), pp.126-126. 10.1051/rphysap:01976001101012600 . jpa-00243952

\section{HAL Id: jpa-00243952 https://hal.science/jpa-00243952}

Submitted on 1 Jan 1976

HAL is a multi-disciplinary open access archive for the deposit and dissemination of scientific research documents, whether they are published or not. The documents may come from teaching and research institutions in France or abroad, or from public or private research centers.
L'archive ouverte pluridisciplinaire HAL, est destinée au dépôt et à la diffusion de documents scientifiques de niveau recherche, publiés ou non, émanant des établissements d'enseignement et de recherche français ou étrangers, des laboratoires publics ou privés. 


\title{
LOCALISATION PAR CANALISATION DES IMPURETÉS IMPLANTÉES DANS LE ZnTe
}

\author{
A. BONTEMPS, J. FONTENILLE, E. LIGEON et R. DANIELOU
}

Section de Physique du Solide, Département de Recherche Fondamentale, Centre d'Etudes Nucléaires de Grenoble, France

\begin{abstract}
Résumé. - La difficulté de créer par implantation ionique des jonctions p-n dans le ZnTe nous a incités à localiser par les techniques de canalisation les impuretés implantées et à suivre leur évolution en fonction de la température de recuit. Les possibilités de localisation étant liées à la solubilité, les données existantes concernant les expériences de localisation dans le Silicium ont été corrélées avec les valeurs disponibles des solubilités limites. Ne disposant d'aucune donnée concernant le $\mathrm{ZnTe}$,nous avons étudié successivement la localisation des éléments de la colonne III (B, Tl), $\mathrm{V}(\mathrm{Bi})$ et VII (F). Nous avons trouvé que le Bismuth se place en position substitutionnelle à la température de recuit de $550^{\circ} \mathrm{C}$.
\end{abstract}

Abstract. - Due to difficulties to design p-n junctions by means of ionic implantation in ZnTe, we have used channelling techniques to locate implanted impurities and to follow their behaviour in function of the anneal temperature. First, we have summarized the available data on lattice location experiments concerning Silicon and have correlated these measurements with the limit solubility values. Then, concerning $\mathrm{ZnTe}$, we studied the lattice location of elements of column III (B, Tl), V (Bi) and VII (F). Bismuth is found to be at a substitutional site for the anneal temperature of $550^{\circ} \mathrm{C}$. 